\title{
Create change
}

\section{Shaping the future of scholarly journal publishing}

\author{
by Ray English and Larry Hardesty
}

I t's time for change. It's time to act collectively and constructively to help solve one of the most pressing problems facing the academic community. It's essential that you be involved.

Here's a concrete example that illustrates the problem. In 1985, an annual library subscription to the yournal of Comparative Neurology cost $\$ 1,920$. Today the price is $\$ 15,000$ ! What's happened to this journal between 1985 and 2000? Its size did increase somewhat, but that factor does not account for the price increase. 'The most significant difference is the fact that a large commercial publisher purchased the journal in 1990. Since then, the subscription price has gone up relentlessly, sometimes by more than $\$ 2,000$ in a single year.

By now you know the problem we're talking about. We librarians call it the "serials crisis." Many academic administrators and faculty have tended to think of it as "the library problem"- - and some have even blamed it on us. In reality it is a higher education issue that can be resolved only by engaging the entire higher education community.

Think with us for a moment about the structure of commercial journal publishing that has evolved over time. Universities and colleges literally give research to commercial publishers who then, in exchange for our generosity, charge us exorbitant prices to receive it in pulblished journal form. Commercial journals rely on faculty and other researchers for virtually all of the substantive content and editorial work related to production of their titles. Faculty submit articles, transfer copyright to the publishers, participate in the system of peer review, and edit the journals' content. Universities and colleges cooperate in this process through their support of faculty research and their tenure and promotion expectations. While no one would object to this arrangement if publishers charged reasonable prices and made reasonable profits, many publishers have taken advantage of the position of libraries in the current system.

The example of the Journal of Comparative Neurology is hardly unique. Commercial publishers have increased journal prices at extraordinary rates and they are realizing profit margins that go far beyond what could otherwise be justified by the nature of their product.

Over the years we've tried various tactics to deal with this problem. We've written angry letters to publishers and editors and had heated debates with publishers' representatives. We've canceled subscriptions and watched our book budgets erode. We've looked to alternative means of information delivery and we've entered into consortial agreements for electronic access. For all our efforts, serial prices continue to rise at unjustified and destructive rates. ${ }^{2}$

\section{About the authors}

Ray English is director of libraries at Oberlin College and a member of the SPARC Steering Committee, e-mail: ray. english@oberlin.edu; Larry Hardesty is college librarian at Austin College and is the current president of ACRL, e-mail: Ihardesty@austinc.edu 


\section{Edftors' introduction}

As we noted in our introduction to this column, changes in scholarly communication have generated widespread discussion and debate.

Much of this discussion has taken place between librarians and publishers. Faculty, researchers, and editorial board members may not be aware of the broader issues beyond their own publications or disciplines.

As leaders in our profession, Larry Hardesty and Ray English ask us all to show leadership by making changes in the schol-

This situation will change only if colleges and universities mobilize concerted and forceful action to take back control of the research produced under their auspices. To accomplish that objective, we need your active involvement and leadership.

\section{The Create Change Initiative}

ACRL, ARL, and SPARC have launched a national initiative designed to engage college and university faculty and administrators in working to reshape the system of scholarly journal publishing. The "Create Change" campaign, which is sponsored by the three organizations in equal partnership, is a broad-based effort to stimulate campus discussion on the nature and origins of the scholarly communication crisis and to make faculty and administrators aware of the options available to them for influencing the future of scholarly journal publishing.

Since the level of awareness of scholarly communications issues among faculty and administrators is at best uneven, the basic strategy of Create Change is to encourage and support individual libraries in coordinating communication and discussion at the campus level. Create Change provides resources and tools that libraries can draw on and adapt to the needs of their institutions.

In addition to positioning libraries to hold public events - such as panel discussions or arly communication system, starting on our own campuses.

They introduce us to Create Change, a program sponsored by ACRL, Association of Research Libraries (ARL), and the Scholarly Publishing and Academic Resources Coalition (SPARC) that will support us all in working with faculty, researchers, editorial board members, and campus administrators to bring about positive changes in the scholarly communication system. - Ivy Anderson, Gail McMillan, and Ann C. Schaffner

talks by outside speakers-Create Change provides supporting information for small- group discussions and one-on-one contact with faculty. Although printed materials are available for distribution, the key to the success of the campaign at the campus level involves personal contacts between librarians, faculty, and administrators. That's where you come in.

The goals of Create Change are to make faculty and administrators aware of the most important aspects of the serials issue, to introduce faculty to specific ways in which they can foster change, and to support and encourage potential faculty leaders in this area. Create Change will build a base of understanding of the issues and offer options for action:

- Editorial boards will be provided with resources to decide whether to move from expensive commercial publishers to nonprofit or independent publishing arrangements.

- Individual facuity can evaluate whether to resign from editorial boards of expensive commercial journals.

- Faculty can decide whether to serve as peer-reviewers for expensive titles.

- Faculty who choose to modify copyright transfer agreements to allow them to retain most rights to their publications will be given templates and models.

- Faculty will have information and tools for engaging in discussion of this set of issues

\section{About the editors}

Ivy Anderson is coordinator for Digital Acqulsitions at Harvard University, e-mail:ivy_anderson@harvard edu; GailMcMillan is head of the Digital Libraryand Archives (formerly the Scholarly Communications Project) at Virginia Tech University, e-mail: gailmac@vt.edu; Ann Schaffner is associate universitylibrarian for Research Services, Instruction \& Planning at Brandeis University, e-mail:schaffne@brandeis.edu 
with peers in their departments and in their scholarly society meetings.

Create Change aims ultimately to initiate a shift in control of scholarly journal publishing, moving research from inordinately expensive commercial journals that no longer serve the interests of the scholarly community to nonprofit and independent publishers, such as university presses, scholarly associations, and small presses. As the example of Michael Rosenzweig's journal Evolutionary Ecology Research dramatically demonstrates, such a shift can have a direct, positive effect on journal prices. ${ }^{3}$

\section{Information and support for libraries}

What happens first? In early June, library directors will have received a mailing about Create Change. The mailing provides an overview of the initiative, its goals and suggested strategies, as well as a list of resources that are available to support a campus communications effort.

Individual libraries may draw on the "Create Change Advocacy Kit," which is available on the Wel) for downloading and customizing for local use at www.crearechange.org. The kit provides information that prepares librarians to communicate with faculty and administrators on the serials issue. Tools in the kit include: 1) a list of frequently asked questions and other background information on the serials crisis, 2) sample materials for use in presentations, 3) tables, charts, and graphs that illustrate scholarly communication issues, 4) sample letters to send with supporting materials to faculty, 5) a summary of available advocacy training services, 6) sample press releases for local use, 7) ads, posters, and other materials designed to reach a broad audience, and 8) information for organizing a campaign at the campus level, including checklists and tips for getting started.

Create Change has also developed a brochure suitalble for clistribution to faculty, which summarizes the serials issue and includes suggestions for individual action. Information for ordering the brochure is available at the Create Change Web site.

Create Change is forming a speakers bureau that can be drawn on in support of local efforts. Scholars and researchers who are knowledgeable and conversant about the serials issue, and who are willing to speak to campus audiences about working for change in scholarly communications, will be listed on the Web site by region. Create Change is also developing an online database of expensive journals. The database will include the names of editors and the editorial boards of each journal with price trend information.

All of these resources should make it practical for an individual library to customize a campus communication strategy that is suitable to local needs.

\section{Information for faculty and administrators}

In addition to providing support for libraries, Create Change has established a Wel site for faculty and administrators, which provides information on both the serials issue and change strategies (also accessible at www createchange.org.) The Web site will assist faculty who wish to become more informed and pursue specific options for change. It includes information on the serials problem, suggestions for specific actions, sample letters to publishers, information on copyright transfer agreements, and information on moving journals and editorial boards from commercial to noncommercial and independent publishing arrangements (with case studies). Faculty will also have access to the database of expensive scholarly journals, with names of the editors and editorial boards.

We expect that coverage of Create Change will also appear in higher education media and in the scientific and disciplinary news sources. Such coverage at the national level will reinforce communication with faculty and administrators at the campus level.

\section{Get involved now}

It is critical that all academic libraries participate in this effort. For many years some commercial journal publishers have subjected libraries to fundamentally unjust pricing practices that limit our ability to respond to faculty needs and place the scholarly communication system in jeopardy. Our individual inaction will only allow this situation to continue. Our collective action will move control of research back into the hands of scholars and have a positive impact on journal prices. This is our chance to reverse past trends and make more information available for schol- 
arship at less cost, rather than the reverse. This is our time to build a new system of scholarly communication that genuinely serves the higher education community. This is our opportunity to Create Change. Don't pass it up.

\section{Notes}

1. The cost per page of the journal increased at a compounded annual rate of $13.5 \%$ between 1985 and 1999, while the cost of the journal itself increased at a compounded rate of $15.2 \%$.
2. According to the most recent Library Journal survey of serials prices, non-U.S. subscriptions will increase by $13.5 \%$ in the year 2000 . U.S. titles will increase by $9.5 \%$, and the composite rate of increase for all subscriptions will be $11.4 \%$ from: Lee Ketcham-Van Orsdel and Kathleen Born, "Periodical Price Survey 2000: Pushing Toward More Affordable Access," Library Journal (April 15, 2000): 51.

3. An annual subscription to Evolutionary Ecology Research is $\$ 272$. An annual subscription to Evolutionary Ecology, its commercial predecessor, is $\$ 784$.

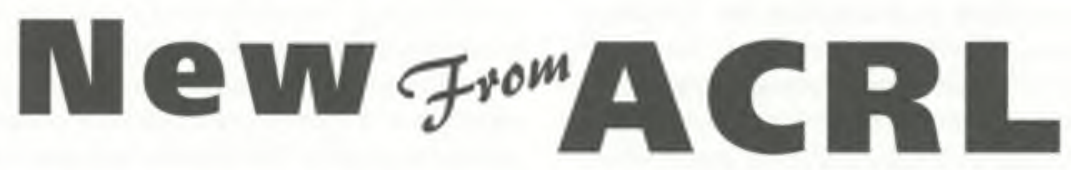

\section{Literature in English: A Guide for Librarians in the Digital}

Age, Publications in Librarianship no. 54

Betty H. Day, William A. Wortman, editors

With sections devoted to resources and collections, and readers and services, this volume is an essential work for librarians who are new, working actively, or simply taking on a new assignment in reference and/or collection development in the field of literature in English. List: \$32.00; ACRL member: \$29.00.

\section{The Collaborative Imperative: Librarians and Faculty Working Together in the Information Universe}

Dick Raspa and Dane Ward, editors

This book will challenge readers to risk engaging in the collaborative process at their institution. List: \$24.00; ACRL member: \$21.50.

\section{Library Web Site Policies, CLIP Note \#29}

Compiled by Jeri L. Traw

This Clip note includes a survey of Web policy practices at college libraries, samples of mission statements, collection development, guidelines and standards, and policy manuals. List: $\$ 25.00 ;$ ACRL member: $\$ 22.50$.

\section{Coming Soon!}

\section{ACRL Trends and Statistics 1999}

Available in two volumes: Carnegie classification Associate of Arts degree granting and Carnegie classifications of Research/Doctoral granting Universities, Master's Colleges and Universities, and Baccalaureate Colleges. Price to be determined.

\section{To Ondex:}

Write: ALA Fulfillment, 155 N. Wacker Drive, Chicago, IL 60606 Call: $800-545-2433$, (press 7) Fax: $312-836-9958$ 